\title{
EMISSION OF HARMFUL GASES FROM POULTRY FARMS AND POSSIBILITIES OF THEIR REDUCTION
}

\author{
JAN BROUČEK ${ }^{1 *}$, BOHUSLAV ČERMÁK ${ }^{2}$ \\ ${ }^{1}$ National Agricultural and Food Centre, Research Institute of Animal Production Nitra, Hlohovecká 2, 95141 Lu- \\ žianky, Slovak Republic; e-mail: broucek@vuzv.sk \\ ${ }^{2}$ University of South Bohemia in České Budějovice, Faculty of Agriculture, Czech Republic \\ ${ }^{*}$ Author for correspondence
}

\begin{abstract}
Brouček J., Čermák B.: Emission of harmful gases from poultry farms and possibilities of their reduction. Ekológia (Bratislava), Vol. 34, No. 1, p. 89-100, 2015.

This review is devoted to methodology that can help to assess emission of gases from poultry housings and could be used to expand the knowledge base of researchers, policymakers and farmers to maintain sustainable environment conditions for farming systems. Concentration and emission of ammonia, methane, nitrous oxide and carbon dioxide in poultry barns are discussed in this paper. Surveys of ammonia and greenhouse gases mean concentrations and emission factors in different poultry systems are showed. This paper is also gives the findings in emission mitigation, especially to different manure handling practices, management schemes, housing and facility designs for broilers and laying hens. Finally this paper focused on investigating practical means to reduce air emissions from animal production facilities.
\end{abstract}

Key words: poultry, emissions, ammonia, methane, nitrous oxide, carbon dioxide, mitigation.

\section{Introduction}

The poultry farms can bring many pollution problems. Therefore, it is important to maintain optimal conditions for poultry production and also it should not impair the human and animal environment through emission of harmful gases. To be profitable, farmers must use the best practices and technological advances in order to achieve the most advantageous environment. The impact on the ecological systems may result from direct release of detrimental constituents into the atmosphere or indirect deposition of these constituents into ground water. The environment in the poultry housing is a combination of physical and biological factors which interact as a complex dynamic system of social interactions, husbandry system, light, temperature and the aerial environment (Hobbs et al., 2004). The high stocking density in the modern poultry barns may lead to reduced air quality with high concentrations of organic and inorganic dust, pathogens and other micro-organisms as well as harmful gases such as ammonia, nitrous oxide, carbon dioxide, hydrogen sulphide, and methane (Ellen, 2005; Gates et al., 2008). 
The production and emission of gases in poultry or any livestock facilities involve complex biological, physical and chemical processes. The rate of emission is influenced by many factors, such as diet composition and conversion efficiencies, manure handling practices and environmental conditions. The composition of poultry diet and the efficiency of its conversion to meat or eggs affect the quantity and physical and chemical properties of the manure. Manure handling practices and environmental conditions also affect chemical and physical properties of the manure, such as chemical composition, biodegradability, microbial populations, oxygen content, moisture and $\mathrm{pH}$ (Xin et al., 2011).

Most gaseous pollutants originate from the breakdown of faecal matter and the concentrations depend on the ventilation efficiency and rate, as well as the stocking density and movements of the animals. The litter type, management, humidity and temperature affect the gas concentration and emission from broiler fattening (Redding, 2013). Also commercial egg production facilities involve variety of housing systems and manure handling practices, which can produce different magnitudes of environmental footprint. However, research information concerning the environmental pollution for various production systems and the system's ability to maintain the microenvironment that is conducive to poultry welfare and health, conservation of natural resources and production efficiency is not very clear.

\section{Ammonia}

Ammonia $\left(\mathrm{NH}_{3}\right)$ is the primary basic gas in the atmosphere. Elevated concentrations of $\mathrm{NH}_{3}$ in poultry barns reduce feed intake and impede bird growth rate, decrease egg production, damage the respiratory tract, increase susceptibility to Newcastle disease virus, increase the incidence of air sacculitis and keratoconjunctivitis and increase the prevalence of Mycoplasma gallisepticum (Kristensen, Wathes, 2000). Egg quality may also be adversely affected by high levels of atmospheric ammonia as measured by reduced albumen height, elevated albumen $\mathrm{pH}$ and albumen condensation (Xin et al., 2011).

The ammonia concentration in the air plays an important role in the neutralisation of atmospheric acids generated by fossil fuel combustion. The reaction product forms a $\mathrm{NH}_{4}^{+}$ aerosol, which is a major component of atmospheric particulates. These $\mathrm{NH}_{4}^{+}$particulates may be transported long distances from the production site before returning to the surface by dry deposition or precipitation. Animal production produces a significant component of anthropogenic $\mathrm{NH}_{3}$ emissions. Ammonia is also a component of odour (Jelínek et al., 2011).

Ammonia volatilisation from manure materials within poultry barns can adversely affect production, and also represents a loss of fertiliser value from the spent litter. It is generated during bacterial decomposition of protein and urea in housing areas and during storage and application of excreta under aerobic and anaerobic conditions (Kristensen et al., 2000). The main source of $\mathrm{NH}_{3}$ is urine of animals. Seventy percent of nitrogenous substances in excrement originate from urine and $30 \%$ from feaces. Poultry feaces contain $60-65 \%$ of uric acid, $10 \%$ of ammonia salts, $2-3 \%$ of urea and remains of creatinine. Especially uric acid is rapidly changed by the microbes to $\mathrm{NH}_{3}$ (Groot Koerkamp, 1994).

Gaseous $\mathrm{NH}_{3}$ is the predominant pollutant in poultry systems. Higher concentrations adversely affect bird performance, welfare and human health (Costa et al., 2012). It is highly reac- 
tive and deposits readily to vegetation and other surfaces close to its source. Intensive animal husbandry units, such as poultry farms, are major sources of ammonia. The reports of Wheeler et al. (2006), Li et al. (2008) and Li and Xin (2010) showed that $80.9 \%$ of total ammonia emissions in USA were from animal husbandry activities, of which $26.7 \%$ were from poultry.

Most agricultural sources tend to be dispersed both temporally and spatially and most of the emitted $\mathrm{NH}_{3}$ may be absorbed by surrounding cropping and natural ecosystems; however, confined animal production tends to be concentrated in relatively small geographical areas and may increase localised nitrogen loading (Harper et al., 2010).

Ammonia emissions are the result of complex physical and chemical processes with the emission rate related to four factors: $\mathrm{NH}_{4}^{+}$concentration of the source, temperature of the source, $\mathrm{pH}$ of the source and the effectiveness of turbulent transport of the $\mathrm{NH}_{3}$ away from the source (Jones et al., 2013). Ammonia emissions are an environmental concern because atmospheric $\mathrm{NH}_{3}$ can significantly alter oxidation rates in clouds and enhance acidic particle species deposition (acid rain). Many factors, such as season of the year, ambient temperature and humidity, bird health and management practices can influence ammonia volatilisation variability from broiler rearing facilities. Indoor ammonia levels are greatly affected by housing and management factors, such as housing type, bird age and density, manure or litter conditions and handling schemes and building ventilation rate (Webb et al., 2005).

Ammonia is released particularly in a hot environment. The factors of temperature and relative humidity that greatly influence $\mathrm{NH}_{3}$ volatilisation are reflection of weather conditions in each season of the year (Mihina et al., 2010). A direct relationship between $\mathrm{NH}_{3}$ emissions and indoor temperature was also observed. Although indoor temperature was identified as main variable influencing $\mathrm{NH}_{3}$ emissions, other variables, such as ventilation rate and bird activity, may also be influencing those emissions (Walker et al., 2014). Ammonia emission rates averaged 19.7 and $18.1 \mathrm{mg} \cdot \mathrm{h}^{-1}$ per bird in the summer and winter, respectively, and increased with indoor temperature $\left(r^{2}=0.51\right.$ in summer; $r^{2}=0.42$ in winter). Emissions are mainly produced at the end of the summer cycle, whereas in winter, their production begins earlier in the cycle (Calvet et al., 2011).

The lowest concentrations of $\mathrm{NH}_{3}$ were recorded in summer period, although ammonia emissions tended to be higher just in summer months because of a higher ventilation rate. The elevated levels of ammonia in winter were attributed to the lower ventilation rate during cold weather. During the fattening period of broilers kept on renewed litter there is an average loss of $6.2 \mathrm{~g}$ ammonia per bird and/or $0.04 \mathrm{~kg}$ of ammonia per bird yearly (Knížatová et al., 2010c). Dolan et al. (2013) found that at the average temperature and relative humidity $23.9{ }^{\circ} \mathrm{C}$ and $57.96 \%$, respectively, in the hall and by the average $1.92 \mathrm{~kg}$ live body weight of birds (in 33rd day of fattening cycle) $\mathrm{NH}_{3}$ production of $7.437 \mathrm{mg} \cdot \mathrm{kg}^{-1} \cdot \mathrm{h}^{-1}$. Knížatová et al. (2010b) showed that in a tunnel-ventilated facility with deep litter, designed for 25,000 broilers, litter temperature and litter age were positively correlated with the production of ammonia gas. The amount of ammonia emissions increased with the litter age as a consequence of both the increased ammonia concentration and the ventilation rate.

Ammonia emission is affected also by litter material, litter humidity and ventilation flow (Patterson, Adrizal, 2005; Mihina et al., 2012a). $\mathrm{NH}_{3}$ emissions varied depending on the litter temperature (Mihina et al., 2012b). The use of new litter material in each cycle determines 
the dynamics of $\mathrm{NH}_{3}$ production. Likewise, distribution of ammonia within the poultry house depends on the ventilation system, particularly the air circulation as well as poorly maintained water drinkers, bird stocking density and flocking behaviour (Kristensen, Wathes, 2000).

All gas emissions increased with bird age. In chickens the concentrations of $\mathrm{NH}_{3}$ rose during fattening periods in all seasons of the year (from 0.23 to $10.77 \mathrm{mg}^{-3} \mathrm{~m}^{-3}$ ). There were inside hall averages of daily (during fattening period of 60 days) emissions of $130 \mathrm{mg} \mathrm{NH}_{3}$ per chicken. Totally $\mathrm{NH}_{3}$ for whole 60 days period was $7.8 \mathrm{~kg}$ per bird (Meda et al., 2011). According to Harper et al. (2010), the ammonia emissions are low at bird placement and increase steadily after the third week of fattening. Total $\mathrm{NH}_{3}$ emissions during the flock growth cycle (from chick placement to flock harvest), giving a farm total of $4,415 \mathrm{~kg}_{\text {of }} \mathrm{NH}_{3} \cdot f l o c k^{-1}$ or $0.016 \mathrm{~kg}$ of $\mathrm{NH}_{3}$. bird $^{-1}$.flock ${ }^{-1}$. Summing the flock cycle and between-flock emissions gives an overall total emission rate of $0.019 \mathrm{~kg}$ of $\mathrm{NH}_{3} \cdot$ bird $^{-1}$.flock ${ }^{-1}$. Wathes et al. (1997), Groot Koerkamp et al. (1998) and Kristensen, Wathes (2000) found mean concentrations of $\mathrm{NH}_{3} 24.2 \mathrm{ppm}$ in broiler houses with peak hourly concentrations exceeding $40 \mathrm{ppm}$.

The commonly recommended $\mathrm{NH}_{3}$ level for US poultry housing has been $14.7 \mathrm{mg} \cdot \mathrm{kg}^{-1}$ (Harper et al., 2010). Costa et al. (2012) compared release of ammonia from laying hen housings. The ammonia concentration was $5.37 \mathrm{mg} \cdot \mathrm{m}^{-3}$ in the battery cages with aerated openmanure storage house, $4.9 \mathrm{mg} \cdot \mathrm{m}^{-3}$ in the vertical tiered battery cages with manure belts and forced-air drying and $3.8 \mathrm{mg} \cdot \mathrm{m}^{-3}$ in the an aviary system housing.

The $\mathrm{NH}_{3}$ emission factors were $15.4 \mathrm{mg} \cdot \mathrm{h}^{-1}$.hen place ${ }^{-1}\left(0.13 \mathrm{~kg} \cdot \mathrm{year}^{-1}\right.$.hen place $\left.{ }^{-1}\right)$ for battery cages with aerated open-manure storage house, $8.26 \mathrm{mg} \cdot \mathrm{h}^{-1}$.hen place $^{-1}\left(0.07 \mathrm{~kg} \cdot \mathrm{year}^{-1}\right.$.hen place $\left.^{-1}\right)$ for vertical tiered cage with manure belts and forced-air drying, and $23.7 \mathrm{mg} . \mathrm{h}^{-1}$.hen place $^{-1}$ (0.21 kg.year ${ }^{-1}$.hen place $\left.{ }^{-1}\right)$ for an aviary-system housing (Costa et al., 2012).

$\mathrm{NH}_{3}$ emissions from the battery system with pit under cages and scraper for manure removal or with an open manure pit under the cages were estimated at 0.220 kg.year ${ }^{-1}$.hen place ${ }^{-1}$ (Costa et al., 2012). Other surveys of ammonia concentrations in different poultry systems showed mean concentrations of $12.3 \mathrm{ppm}$ in perchery systems with peak hourly concentrations exceeding 40 ppm (Wathes, 1998; Groot Koerkamp et al., 1998; Kristensen, Wathes, 2000). Feddes, Licsko (1993) found ammonia concentrations in turkey grower barns to be above $10 \mathrm{ppm}$ while Kristensen, Wathes (2000) recommended that ammonia concentrations in turkey houses should not exceed $15 \mathrm{ppm}$.

\section{Greenhouse gases}

In animal housing there are several factors that affect the production and release of harmful gaseous compounds. These are primarily the number and live weight of housed animals, floor surface covered with their excrements, manure storage time in housing area, performance of ventilation system, air temperature, year season, air movement above the litter surface or not bedded barn floor, air penetration through the litter, litter temperature, moisture, $\mathrm{pH}$, the $\mathrm{C}: \mathrm{N}$ ratio and feed composition (Knowlton, 2000; Wheeler et al., 2003; Coufal, 2006; Mihina et al., 2012a).

Much of the greenhouse gases (GHG) generated from the poultry industry is primarily from feed production (Dunkley et al., 2013). Numerous factors affect the emission of these 
gases from broiler facilities. Xin et al. (2011) evaluated more of studies directed on formation of greenhouse gas emissions from poultry houses. The results showed that $90 \%$ of the emissions from the broiler and pullet farms were originally from propane and diesel gas use, but only $6 \%$ from laying hen farms. On laying hen farms, about $29 \%$ of GHG emissions were the result of electricity use while the pullet and broiler farms had only 3\% emissions from electricity use. Emissions from manure management in the layer facility were responsible for $53 \%$ of the total emission from the facility, while electricity use represented $28 \%$ of the total emissions.

\section{Methane}

Methane $\left(\mathrm{CH}_{4}\right)$ is greenhouse gas with high global warming potential, which is 23 times the greenhouse effect of carbon dioxide. Due to the digestive physiology, poultry are monogastric and produce only slightly amounts of $\mathrm{CH}_{4}$ (Pedersen et al., 2008). However, methane can be generated in the animal housing, manure storage and during manure application, by fermentation of organic matter (Brouček, 2014). A similar microbial process to enteric fermentation of ruminants also leads to methane production from stored manure. Additionally, small amounts of methane are produced from manure deposited on grasing lands (Redding, 2013). However, it is not well understood whether considerable amounts of $\mathrm{CH}_{4}$ may be emitted from litter reactions inside the building, depending on the litter management and conditions (Calvet et al., 2011).

Despite this finding, Meda et al. (2011) show averages of daily concentrations per chicken is $13 \mathrm{mg} \mathrm{CH}_{4}$ and totally for whole 60 days period $0.8 \mathrm{~kg}$ per bird. Calvet et al. (2011) found $\mathrm{CH}_{4}$ emissions of 0.44 and $1.87 \mathrm{mg} \cdot \mathrm{h}^{-1}$ per bird in summer and winter, respectively. Dolan et al. (2013) measured concentrations of harmful gases in broilers barn during $24 \mathrm{~h}$ at the average body weight $1.92 \mathrm{~kg}$ of bird and recorded $82.636 \mathrm{mg} \cdot \mathrm{kg}^{-1} \cdot \mathrm{h}^{-1}$ of $\mathrm{CH}_{4}$.

\section{Nitrous oxide}

Nitrous oxide $\left(\mathrm{N}_{2} \mathrm{O}\right)$ is a very potent greenhouse gas, with 310 times greater global warming potential than carbon dioxide (Oenema et al., 2005).

$\mathrm{N}_{2} \mathrm{O}$ in the atmosphere has a long life and contributes significantly to global warming. It is converted to NO, which decomposes stratospheric ozone that protects Earth from harmful ultraviolet radiation (Hardy, 2003; Schulze et al., 2009). This gas is related to the agricultural nitrogen cycle. Excess nitrogen in agriculture systems can be converted to nitrous oxide through the nitrification-denitrification process.

$\mathrm{N}_{2} \mathrm{O}$ can be produced in soils following inorganic and organic fertilizer application and also from manure storage surfaces (Redding, 2013). Nitrous oxide is generated by the microbial conversion of nitrates in excreta during their storage and applications (Oenema et al., 2005). The production of $\mathrm{N}_{2} \mathrm{O}$ from poultry manure depends on feaces composition, microbes and enzymes involved and the conditions after excretion.

Meda et al. (2011) found daily emission of $46 \mathrm{mg} \mathrm{N} \mathrm{N}_{2} \mathrm{O}$ per chicken and for whole 60 days period $2.8 \mathrm{~kg}$ per bird. Average $\mathrm{N}_{2} \mathrm{O}$ emissions were in the study of Calvet et al. (2011) $1.74^{1}$ and $2.13 \mathrm{mg} \cdot \mathrm{h}^{-1}$ per bird in summer and winter, respectively. Dolan et al. (2013) found $\mathrm{N}_{2} \mathrm{O}$ value of $0.409 \mathrm{mg} \cdot \mathrm{kg}^{-1} \cdot \mathrm{h}^{-1}$, 2 days before end of fattening ( $30^{\text {th }}$ day, body weight $1.92 \mathrm{~kg}$ of bird $)$. 


\section{Carbon dioxide}

The main source of carbon dioxide in livestock is animal respiration, combustion of natural gas for heating and cooking, and decomposition of organic matter (Knížatová et al., 2010a). The high emission from propane use in broiler and pullet houses due to heating the houses during brooding and cold weather (Calvet et al., 2011). There is also a link between metabolism and animal production of $\mathrm{CO}_{2}$ (Mihina et al., 2012b). Carbon dioxide production by birds is proportional to their metabolic heat production, and thus to the metabolic body weight of the birds, which in turn is affected by the temperature and bird activity. The animal $\mathrm{CO}_{2}$ production under normal farm conditions has normally a diurnal variation of $\pm 20 \%$ (Pedersen et al., 2008).

Carbon dioxide $\left(\mathrm{CO}_{2}\right)$ concentrations and emissions were assessed over six fattening periods in the study of Knížatová et al. (2010d). The major part of $\mathrm{CO}_{2}$ seemed to have its origin from bird respiration with assumed production of approx. $147 \mathrm{~kg}$ of $\mathrm{CO}_{2} \cdot \mathrm{h}^{-1} \cdot \mathrm{CO}_{2}$ emission was most affected by chickens towards the end of the fattening period taking dominance over the process of natural gas burning by heaters. The mean $\mathrm{CO}_{2}$ emission from the chicken house ranged between 120 and $247 \mathrm{~kg} \cdot \mathrm{h}^{-1}$ in the first quarter of periods and between 325 and 459 $\mathrm{kg} . \mathrm{h}^{-1}$ in the last ones. The heaters could be theoretically a possible source of approximately 39 $\mathrm{kg} \mathrm{CO} 2$ each hour if they worked continuously. $\mathrm{CO}_{2}$ emissions were considerably more affected by ventilation rate than by $\mathrm{CO}_{2}$ concentration in the indoor air. Knížatová et al. (2010b) did not find difference in emissions of $\mathrm{CO}_{2}$ between fattening periods (seasons). After the evaluation of carbon dioxide measures, it can be concluded that there is an average releasing of $10.4 \mathrm{~kg} \mathrm{CO}$ per bird and fattening period and/or $73.11 \mathrm{~kg} \mathrm{CO}_{2}$ per bird yearly. Carbon dioxide with peaks even three times higher than it is allowed $(\geq 3000 \mathrm{ppm})$. For that reason, not only the temperature but also the amount of air released from poultry buildings and the content of $\mathrm{CO}_{2}$ in air should be new variables in operating ventilation system. According to Calvet et al. (2011), average $\mathrm{CO}_{2}$ emission rates were 3.84 and $4.06 \mathrm{~g} \cdot \mathrm{h}^{-1}$ per bird in summer and winter, respectively.

\section{Emissions mitigation}

Increasing attention must be devoted to investigating to reduce air emissions possibilities from animal housings. High levels of noxious gases, especially ammonia, causing poor environmental conditions for the birds and the workers inside the house as well as for the neighbours. Primary action to reduce emissions is to modify housing and manure handling.

\section{Housing and manure treatment}

Agriculture accounts for 10-12\% of the World's total GHG emissions. Manure management alone is responsible for $13 \%$ of GHG emissions from the agricultural sector. During the last decades, farming production systems have shifted from deep-pit housing systems to manure belt housing systems (Fournel et al., 2012).

In the manure belt cage housing system, fresh manure (approximately $75 \%$ moisture) drops onto a belt beneath each row of cages. Manure on the belt is either dried 'naturally' by 
the ventilation air or a forced-air stream directed, through an air duct under the cages, over the manure surface. At a given interval, ranging from daily to weekly, the manure is conveyed via the belt to one end of the house and removed to an on-farm or off-farm storage or composting facility or land application. Depending on natural or forced drying on the belt and the seasonal climate, manure leaving manure belt houses will have a moisture content of less than $30-60 \%$. Lower moisture content manure is easier to transport and emits less ammonia. On a per-hen basis, manure belt cage systems are generally $50 \%$ higher in capital costs than their high rise manure removing counterparts; however, manure belt systems offer considerable benefits. Manure removal from manure belt houses is less labor-intensive than the other methods, but maintenance of the belt conveyor is critical (Li, Xin, 2010).

The cage housing for laying hens are a system with manure removal, at least twice a week (better every day), by way of manure belts to a closed storage $\left(\mathrm{NH}_{3}\right.$ emission reduction is estimated in 58-76\%); vertically tiered cages with manure belt with forced-air drying in which the manure is removed at least once a week to a covered storage (reduction of $\mathrm{NH}_{3}$ emission is 58-88\%); and vertically tiered cages with manure belt, with drying tunnel over the cages, the manure is removed to a covered storage after $24-36 \mathrm{~h}$ (reduction of $\mathrm{NH}_{3}$ emission is estimated to be 80 ). For non-cage housing system with deep litter system and perforated floor is $\mathrm{NH}_{3}$ emission reduction estimated at $0.315 \mathrm{~kg}$.year ${ }^{-1}$.hen place $^{-1}$. The non-cage housing with deep litter and forced-air drying has reduction of $\mathrm{NH}_{3}$ emissions estimated at $60 \%$, and a deep litter system with a partly perforated floor and forced-air drying and an aviary system with or without range or outside scratching area have $\mathrm{NH}_{3}$ emissions estimated on the levels of 65 and 71\% (Costa et al., 2012).

Fournel et al. (2012) published a comparative study conducted to identify the housing system with the least impact on the environment. GHG emissions were measured from three different cage layer housing systems. Deep liquid manure pit housing systems consist of cages located over a closed pit containing the hens' droppings to which water is added to facilitate removal by pumping. Manure belt techniques imply that manure drops on a belt beneath each row of battery cages where it is either dried naturally or by forced air until it is removed. The results showed that liquid manure from deep-pit housing systems produces greater emissions of $\mathrm{CH}_{4}, \mathrm{~N}_{2} \mathrm{O}$ and $\mathrm{CO}_{2}$ than natural and forced dried manure from belt housing systems. The influencing factors appeared to be the manure removal frequency and the dry matter content of the manure.

The natural and forced air manure belt systems reduced $\mathrm{CH}_{4}\left(25.3\right.$ and 27.7 g.year ${ }^{-1}$. hen ${ }^{-1}$, respectively), $\mathrm{N}_{2} \mathrm{O}$ (2.60 and 2.48 g.year ${ }^{-1}$.hen ${ }^{-1}$, respectively) and $\mathrm{CO}_{2}$ (28.2 and 28.7 kg.year ${ }^{-1}$.hen ${ }^{-1}$, respectively) emissions in comparison with the deep-pit technique $\left(\mathrm{CH}_{4} 31.6\right.$ g.year ${ }^{-1}$.hen ${ }^{-1}, \mathrm{~N}_{2} \mathrm{O} 2.78$ g.year ${ }^{-1}$.hen ${ }^{-1}$, and $\mathrm{CO}_{2} 36.0$ kg.year ${ }^{-1}$.hen ${ }^{-1}$ ) (Fournel et al., 2012).

Belt manure using improves the quality housing environment over the years. Indoor air quality, especially ammonia and dust levels, of manure belt houses is generally much better than that with other manure management practices (high rise manure removing or littered floor rearing systems) (Green et al., 2009). The another factor, namely the frequent manure removal, also results in significantly lower $\mathrm{NH}_{3}$ emissions from manure belt housing than manure scraper removing houses ( $\mathrm{Li}$ et al., 2011). It should be noted that manure storage for manure belt houses also contributes to harmful emissions (Chai et al., 2010). 
The manure drying system consists of one or more tiers with direct chain driven revolving steel plates. These plates are perforated (35\% of the surface is open), allowing air to go through fast and better drying of the manure. The chain runs on a rail and moves the plates in such a way that no manure can get in contact with and harm the moving parts. The droppings, coming from the manure belts in the poultry house are evenly distributed over the rotating top layer of the manure drying tunnel. As soon as the manure reaches the end of the first layer the perforated plate tilts and drops the manure automatically on the plates of the level below to continue its way in the opposite direction through the tunnel to release more moisture. Forced tilting of the perforated drying plates at each level guarantees no clogging and no manure sticking on the plates. In the other technique, ventilation air is blown at high pressure through the system to reach a dry matter content of $80-85 \%$ in less than 72 $\mathrm{h}$, depending on the atmospheric humidity. Drying manure to over $80 \%$ dry matter content reduces odour and $\mathrm{NH}_{3}$ (Sluis, 2012).

\section{Exhaust air treatment}

To clean used chemicals in a broiler or layer house, air cleaners are installed. These cleaners have plastic filters which are sprinkled with liquid that captures $\mathrm{NH}_{3}$. Droplet separators are used to separate the fluid droplets from the airstream. Around $58 \%$ of the total amount of emissions that is normally discharged through the chimney is collected (Lyngbye et al., 2013)

In houses with fans can be used to evacuate polluted air in fast manner through ventilation. The treatment may use also some type of impact curtains or biomass stack-wall. However, harmful emissions are only dispersed, no removed. Vegetative environmental buffers (trees were planted in the downstream of the exhaust air) have also been used by egg and meat producers in an attempt to reduce environmental impact of the exhaust air (Corkery et al., 2013). More recently, wet scrubbers are being investigated with the aim to precipitate dust, $\mathrm{NH}_{3}$ and odour from the exhausted air. However, for poultry housing, the biggest challenge is the obstruction of the filtration system by feathers. The system is also rather energyintensive because extra energy is used to overcome the resistance to the air flow (Xin et al., 2011).

\section{Litter treatment}

The basic litter materials used for poultry is straw include wood shavings. Manure, wasted feed and feathers accumulate in the bedding, forming a nutrient-rich substrate that may subsequently become a fertiliser source. The way to manure store during the composting process affects $\mathrm{NH}_{3}$ emissions ( $\mathrm{Li}, 2006$; $\mathrm{Li}, \mathrm{Xin}, 2010$ ). It is important that spreading the manure into thin layers would gives rise to higher emissions than stacking it into thicker layers. Higher moisture content is associated with higher emissions, as is warmer environmental temperature.

Redding (2013) compared the ability of alum and bentonite to decrease volatilisation losses of ammonia from poultry litter. Bentonite additions were superior to alum additions at retaining spent litter ammonia. Application of bentonite may prevent nitrogen losses, possibly 
providing a more effective input material for a fertiliser product (Gillman, 2006; Redding, 2013). Application may provide a production benefit by higher growth rates due to decreased atmospheric ammonia concentrations, and decreased expenditure on other bedding materials (Redding, 2013).

Li et al. (2008) reported that liquid alum reduced ammonia fluxes by $32 \%$ from laying hen manure. In a series of studies (five treatment agents, including zeolite, liquid aluminum sulfate, granular aluminum sulfate, granular ferric sulfate and sodium bisulfate were topically applied to stored laying hen manure removed from a manure belt house. In all cases, application of the treatment agents showed reduction (33 to 94\%) in ammonia emissions over a 7-d manure storage period (Xin et al., 2011).

\section{Nutritional treatment}

Dietary manipulation can be an effective means to lower ammonia emissions by reducing excessive nitrogen excretion or change of manure $\mathrm{pH}$. Liu et al. (2011) recorded that a nutritionally balanced feed ration with decreased crude protein content led to decrease in annual $\mathrm{NH}_{3}$ emission with no adverse effect on egg production. Kristensen, Wathes (2000) wrote that inclusion of high-fiber ingredients in laying hen feeds lowered $\mathrm{NH}_{3}$ emission from the manure.

Increased bacterial fermentation of the dietary fiber in the intestine produces acetate, butyrate and propionate fatty acids, which decrease the $\mathrm{pH}$ of the manure (Wathes, 1998). The lower $\mathrm{pH}$ shifts develops more ammonium ion $\left(\mathrm{NH}_{4}^{+}\right)$. The study of Liu et al. (2011) showed that diets containing three supplemental amino acids resulted in lower nitrogen excretion (by $12 \%$ ) and a lower cumulative loss of ammonia (by 23\%) when compared with diets containing only two supplemental amino acids.

The findings also demonstrate that although dietary treatments may reduce losses in the form of gaseous emissions, litter or excreta composition may not reflect the differences in gaseous losses that occur, and therefore may not serve as an indicator of the potential for reducing air emissions by using feeding methods (Liu et al., 2011).

Bio alginates are successfully applied in human and veterinary medicine. Interesting thing is the ability of these bio alginates to absorb catabolic gases, particularly $\mathrm{NH}_{3}$, which is produced during digestion and conversion of nitrogen compounds (Čermák et al., 2010). Hydrolysed brown algae (Ascophyllum nodosum) is prepared to follow the line of plant products from algae.

The hydrolysed marine brown algae A. nodosum recommend by Čermák et al. (2010) added into pelleted feed (injection during pelleting) or into drinking water of broilers. They observed selected physical and chemical parameters and parameters related to fattening and zoo sanitary state. In the first phase, the preparation was injected into pelleted feed mix. Hydrolysed marine brown algae A. nodosum was added from the very beginning of the fattening in the following ratio: $400 \mathrm{~g} \cdot \mathrm{t}^{-1}$ of feed mixture (instead of the same amount of wheat). The second phase consisted of two trials in which the hydrolysed preparation was added in fixed concentrations (1:1400 - 1600 or 1:1600 - 1700) into drinking water. The results show a positive influence on production hall environment. The concentration of $\mathrm{NH}_{3}$ in the trial 
hall was no significantly lower than in the control hall. The treated broiler chickens decreased the mortality about $1.8 \%$.

\section{Conclusion}

The intention of this review is to document and compare the results of previous studies on emissions assessment, in particular housing situations and to demonstrate the impact and significance of the environmental problem for farm animal welfare, housing, design and management.

Current poultry farm planners and policymakers must adapt to the ever increasing demands on quality of animal and human environment. Poultry owners must continually seek advances in housing technology to improve their farms in order to remain competitive and be successful.

However, further research is still needed. Scientists must focus on indoor air quality; the causes of emissions, especially in alternative hen housing systems and enriched cage systems; environmental footprint for different poultry production systems through life cycle assessment and practical means to mitigate air emissions from production systems.

\section{Acknowledgements}

This article was possible through projects APVV-0632-10 of the Slovak Research and Development Agency Bratislava, and NAZVA QH 92252.

\section{References}

Brouček, J. (2014). Methods of methane measurement in ruminants. Slovak Journal of Animal Science, 47(1), 51-60. Calvet, S., Cambra-Lopez, M., Estelles, F. \& Torres A.G. (2011). Characterization of gas emissions from a Mediterranean broiler farm. Poult. Sci., 90, 534-542. DOI: 10.3382/ps.2010-01037.

Chai, L.L., Ni, J.Q., Chen, Y., Diehl, C.A., Heber, A.J. \& Lim T.T. (2010). Assessment of long-term gas sampling design at two commercial manure-belt layer barns. Journal of the Air \& Waste Management Association, 60, 702-710. DOI: 10.3155/1047-3289.60.6.702.

Corkery, G., Ward, S., Kenny, C. \& Hemmingway P. (2013). Incorporating smart sensing technologies into the poultry industry. Journal of World's Poultry Research, 3(4), 106-128. http://jwpr.science-line.com/

Costa, A., Ferrari, S. \& Guarino M. (2012). Yearly emission factors of ammonia and particulate matter from three laying-hen housing systems. Animal Production Science, 52, 1089-1098. DOI: 10.1071/AN11352.

Coufal, C.D., Chavez, C., Niemeyer, P.R. \& Carey J.B. (2006). Nitrogen emissions from broiler measured by mass balance over eighteen consecutive flocks. Poult. Sci., 85, 384-391. DOI: 10.1093/ps/85.3.384.

Čermák, B., Hnisová, J., Petrášková, E., Šoch, M., Kadlec, J., Lád, F. \& Vostoupal B. (2010). The influence of the different levels of crude proteins in feed mixture for pigs and poultry and biopolym adition to concentrate for farm building microclimate. Scientific Papers: Animal Science and Biotechnologies, 43(1), 26-28.

Čermák, B., Hnisová, J., Petrášková, E., Šoch, M. \& Vostoupal B. (2011). Influence of biological agents. Effect on reduction of ammonia concentration in stables of intensive farm animals breeding. Scientific Papers: Animal Science and Biotechnologies, 44(1), 482-485.

Dolan, A., Ludačková, J. \& Pražma F. (2013). Measurement and evaluation of emission gasses production in the selected poultry farm (in Czech). In Sborník mezinárodní vědecké konference: Technika pro zemědělské, komunální a environmentální technologie, oponované př́spěvky jako součást časopisu Komunální technika, 7(5), 6. Praha: Profi Press.

Dunkley, C.S., Fairchild, B.D., Ritz, C.W., Kiepper, B.H. \& Lacy M.P. (2013). Estimation of on-farm greenhouse gas emissions from poultry houses. In Proceedings from Waste to Worth "Spreading" Science and Solutions 2013. 
Denver. http://www.extension.org/67591

Ellen, H.H. (2005). Emissions, regulations and impact in the European Union and The Netherlands. Journal of Applied Poultry Research, 14, 651-655. DOI: 10.1093/japr/14.3.651.

Feddes, J.J.R. \& Licsko Z.J (1993). Air quality in commercial turkey housing. Canadian Agricultural Engineering, $35,147-150$.

Fournel, S., Pelletier, F., Godbout, S., Lagacé, R. \& Feddes J. (2012). Greenhouse gas emissions from three cage layer housing systems. Animals, 2, 1-15. DOI: 10.3390/ani2010001.

Gates, R.S., Casey, K.D., Wheeler, E.F., Xin, H. \& Pescatore A.J. (2008). U.S. broiler ammonia emissions inventory model. Atmos. Environ., 42, 3342-3350. DOI: 10.1016/j.atmosenv.2007.06.057.

Gillman, G.P. (2006). Converting feedlot waste to fertilizer using charged clays: environmental and economic benefits. Environmental Quality Management, 16, 73-80. DOI: 10.1002/tqem.20122.

Green, A.R., Wesley, I., Trampel, D.W. \& Xin H. (2009). Air quality and hen health status in three types of commercial laying hen houses. Journal of Applied Poultry Research, 18, 605-621. DOI: 10.3382/japr.2007-00086.

Groot Koerkamp, P.W.G. (1994). Review on emissions of ammonia from housing systems for laying hens in relation to sources, processes, building design and manure handling. Journal of Agricultural Engineering, 59, 73-87. DOI: $10.1006 /$ jaer.1994.1065.

Groot Koerkamp, P.W.G., Metz, J.H.M., Phillips, V.R., Holden, M.R., Sneath, R.W., Short, J.L., White, R.P, Hartung, J., Seedorf, J., Schröder, M., Linkert, K.H., Pedersen, S., Takai, H., Johsen, J.O. \& Wathes C.M. (1998). Concentrations and emissions of ammonia in livestock buildings in Northern Europe. Journal of Agricultural Engineering Research, 70, 79-95. DOI: 10.1006/jaer.1998.0275.

Hardy, J.T. (2003). Climate change: causes, effects, and solutions. Chichester: John Wiley \& Sons.

Harper, L.A., Flesch, T.K. \& Wilson J.D. (2010). Ammonia emissions from broiler production in the San Joaquin Valley. Poult. Sci., 89, 1802-1814. DOI: 10.3382/ps.2010-00718.

Hobbs, P.J., Webb, J., Mottram, T.T., Grant, B. \& Misselbrook T.M. (2004). Emissions of volatile organic compounds originating from UK livestock agriculture. Journal of Science of Food and Agriculture, 84, 1414-1420. DOI: $10.1002 /$ jsfa.1810.

Jelínek, A., Dolan, A. \& Vávra V. (2011). Metodika měřní emisi amoniaku $\left(\mathrm{NH}_{3}\right)$ a oxidu uhličitého $\left(\mathrm{CO}_{2}\right) v$ chovech drůbeže ve vztahu k integrované prevenci a omezení znečištění (IPPC). Celostátní metodika pro Mze ČR. České Budějovice: Jihočeská univerzita.

Jones, L., Nizam, M.S., Reynolds, B., Bareham, S. \& Oxley E.R.B. (2013). Upwind impacts of ammonia from an intensive poultry unit. Environ. Pollut., 180, 221-228. DOI: 10.1016/j.envpol.2013.05.012.

Knížatová, M., Brouček, J. \& Mihina Š. (2010a). Seasonal differences in levels of carbon dioxide and ammonia in broiler housing. Slovak Journal of Animal Science, 43, 105-112.

Knížatová, M., Mihina, Š., Brouček, J., Karandušovská, I. \& Mačuhová J. (2010b). Ammonia emissions from broiler housing facility: influence of litter properties and ventilation. XVIIth World Congress of the International Commission of Agricultural and Biosystems Engineering (CIGR). Canadian Society for Bioengineering (CSBE/ SCGAB) Québec City, Canada, June 13-17.

Knížatová, M., Mihina, Š., Brouček, J., Karandušovská, I. \& Mačuhová J. (2010c). The influence of litter age, litter temperature and ventilation rate on ammonia emissions from a broiler rearing facility. Czech Journal of Animal Science, 55, 337-345.

Knížatová, M., Mihina, Š., Brouček, J., Karandušovská, I., Sauter, G.J. \& Mačuhová J. (2010d). Effect of the age and season of fattening period on carbon dioxide emissions from broiler housing. Czech Journal of Animal Science, $55,436-444$.

Knowlton, K.F. (2000). Ammonia emissions: the next regulatory hurdle. The Jersey Journal, 47(10). 56-57.

Kristensen, H.H. \& Wathes C.M. (2000). Ammonia and poultry welfare: a review. World's Poultry Science Journal, 56, 235-245. DOI: 10.1079/WPS20000018.

Kristensen, H.H., Burgess, L.R., Demmers, T.G.M. \& Wathes C.M. (2000). The preferences of laying hens for different concentrations of atmospheric ammonia. Appl. Anim. Behav. Sci., 68, 307-318. DOI: 10.1016/S01681591(00)00110-6.

Li, H., Xin, H., Liang, Y. \& Burns R.T. (2008). Reduction of ammonia emissions from stored laying hen manure through topical application of zeolite, $\mathrm{Al}+\mathrm{Clear}$, Ferix-3, or poultry litter treatment. Journal of Applied Poultry Research, 17, 421-431. DOI: 10.3382/japr.2007-00076.

Li, H. \& Xin H. (2010). Lab-scale assessment of gaseous emissions from laying-hen manure storage as affected by physical and environmental factors. Transactions of the ASABE, 53, 593-604. DOI: 10.13031/2013.29574. 
Li, S., Li, H., Xin, H. \& Burns R.T. (2011). Particulate matter concentrations and emissions of a high-rise layer house in Iowa. Transactions of the ASABE, 54, 1093-1101. DOI: 10.13031/2013.37101.

Liu, Z., Powers, W., Karcher, D., Angel, R. \& Applegate T.J. (2011). Effect of Amino Acid Formulation and Supplementation on Nutrient Mass Balance in Turkeys. Poult. Sci., 90, 1153-1161. DOI: 10.3382/ps.2010-01082.

Lyngbye, M. (2013). The first air cleaner for poultry with $80 \%$ ammonia reduction. International Poultry Production, 21(7), 27-28.

Meda, B., Hassouna, M., Fléchard, C., Lecomte, M., Germain, K., Picard, S., Cellier, P. \& Robin P. (2011). Housing emissions of $\mathrm{NH}_{3}, \mathrm{~N}_{2} \mathrm{O}$ and $\mathrm{CH}_{4}$ and outdoor emissions of $\mathrm{CH}_{4}$ and $\mathrm{N}_{2} \mathrm{O}$ from organic broilers. In J. Köfer \& $\mathrm{H}$. Schobesberger (Eds.), Proceedings of the XVth International Congress of the International Society for Animal Hygiene (pp. 215-218). Tribun, EU.

Mihina, Š., Knížatová, M. \& Brouček J. (2010). Effect of season on carbon dioxide and ammonia production in broiler housing. In Selected problems of soil tillage systems and operations (pp. 123-133). Warsaw: Faculty of Production Engineering, Warsaw University of life Sciences.

Mihina, S., Kazimirova, V. \& Copland T.A. (2012a). Technology for farm animal husbandry. Nitra: Slovak Agricultural University.

Mihina, Š., Sauter, M., Palkovičová, Z., Karandušovská, I. \& Brouček J. (2012b). Concentration of harmful gases in poultry and pig houses. Animal Science Papers and Reports, 30, 395-406.

Oenema, O., Wrage, N., Velthof, G. L., Groenigen, J. W., Dolfing, J. \& Kuikman P.J. (2005). Trends in global nitrous oxide emissions from animal production systems. Nutr. Cycl. Agroecosyst., 72, 51-56. DOI: 10.1007/s10705004-7354-2.

Patterson, P.H. \& Adrizal A. (2005). Management strategies to reduce air emissions: Emphasis - dust and ammonia. Journal of Applied Poultry Research, 14, 638-650. DOI: 10.1093/japr/14.3.638.

Pedersen, S., Blanes-Vidal, Jørgensen, H., Chwalibog, A., Haussermann, A., Heetkamp, M.J.W. \& Aarnink A.J.A. (2008). Carbon dioxide production in animal houses: a literature review. CIGR Journal, 10, 1-19.

Redding, M.R. (2013). Bentonite can decrease ammonia volatilisation losses from poultry litter: laboratory studies. Animal Production Science, 53, 1115-1118. DOI: 10.1071/AN12367.

Sluis van der, W. (2012). Drying poultry manure to protect the environment. World Poultry, 28(8), 22-23.

Xin, H., Gates, R.S., Green, A.R., Mitloehner, F.M., Moore Jr., P.A. \& Wathes C.M. (2011). Environmental impacts and sustainability of egg production systems. Poult. Sci., 90, 263-277. DOI: 10.3382/ps.2010-00877.

Walker, J.T., Robarge, W.P. \& Austin R. (2014). Modeling of ammonia dry deposition to a pocosin landscape downwind of a large poultry facility. Agriculture, Ecosystems and Environment, 185, 161-175. DOI: 10.1016/j. agee.2013.10.029.

Wathes, C.M. (1998). Aerial emissions from poultry production. World's Poultry Science Journal, 54, $241-251$. DOI: 10.1079/WPS19980016.

Webb, J., Menzi, H., Pain, B.F., Misselbrook, T.H., Dämmgen, U., Hendriks, H. \& Döhler H. (2005). Managing ammonia emissions from livestock production in Europe. Environ. Pollut., 135, 399-406. DOI: 10.1016/j.envpol.2004.11.013.

Wheeler, E.F., Casey, K.D., Zajaczkowski, J.S., Topper, P.A., Gates, R.S., Xin, H., Liang, Y. \& Tanaka A. (2003). Ammonia emissions from U.S. poultry houses: part III- broiler houses. In Proc. 3rd International Conference on Air Pollution from Agricultural Operations (pp. 159-166). St. Joseph: American Society of Agricultural Engineers.

Wheeler, E.F., Casey, K.D., Gates, R.S., Xin, H., Zajaczkowski, J.L., Topper, P.A., Liang, Y. \& Pescatore A.J. (2006). Ammonia emissions from twelve U.S.A. broiler chicken houses. Transactions the ASABE, 49, 1495-1512. DOI: $10.13031 / 2013.22042$. 